\title{
Comparative Study of Psychosocial Development Between Former Teenagers and Non Drug Users at Yayasan Ar-Rahman
}

\author{
$1^{\text {st }}$ Yunike \\ Nursing Department \\ Poltekkes Kemenkes Palembang \\ Palembang, Indonesia \\ yunike@ poltekkespalembang.ac.id
}

\author{
$2^{\text {nd }}$ Ira Kusumawaty \\ Nursing Department \\ Poltekkes Kemenkes Palembang \\ Palembang, Indonesia \\ irakusumawaty@poltekkespalembang.ac.id
}

\author{
$3^{\text {rd }}$ Yeni Elviani \\ Nursing Department \\ Poltekkes Kemenkes Palembang \\ Palembang, Indonesia \\ yenielviani@poltekkespalembang.ac.id
}

\author{
$4^{\text {th }}$ Rheviani Atrisha \\ Nursing Department \\ Poltekkes Kemenkes Palembang \\ Palembang, Indonesia \\ rheviani@gmail.com
}

\author{
$5^{\text {th }}$ Nadinda Nathania \\ Nursing Department \\ Poltekkes Kemenkes Palembang \\ Palembang, Indonesia \\ nadindanathania7@gmail.com
}

Corresponding author: irakusumawaty@ poltekkespalembang.ac.id

\begin{abstract}
Psychosocial development is a development which includes emotional, social, cognitive, and moral development. The stages of psychosocial development in adolescents are looking for self-confidence and personal identity. If the stage of identity development is inadequate, psychosocial problems will be created in adolescents such as low self-esteem, depression, drug use, and low school performance. The purpose of this study was to determine differences in psychosocial development between adolescent former users and non-drug users in the Ar- Rahman Foundation. This research is a quantitative study using a comparative study design. The sampling method in this study uses total sampling techniques in adolescent former drug users in the ArRahman Rehabilitation Foundation and purposive sampling techniques in non-drug adolescents in Madrasah Aliyah Ar- Rahman. The sample used in this study was 36 samples consisting of 18 samples of adolescent former drug users and 18 non-drug adolescent sample. The results of the analysis using the Two Independent Sample Test with the Mann Whitney U Test type is known that the value of $p$ value $(0.118)>\alpha(0.05)$ concluded that $\mathrm{Ha}$ was rejected. This study concluded that there is no difference in psychosocial development between adolescent former drug users in the Ar- Rahman Rehabilitation Foundation and adolescent non-drug users in Madrasah Aliyah Ar-Rahman. The results of this study can be input for screening psychosocial development in adolescents so they can make appropriate interventions early.
\end{abstract}

Keywords: Psychosocial development, adolescents, historyof drug use.

\section{INTRODUCTION}

Adolescence is a period of transition from childhood to adulthood characterized by physical, mental, emotional and social development [1]. According to the World Health Organization (WHO), the category of adolescents is those aged 10-19 years [2]. According to the Regulation of the Minister of Health of the Republic of Indonesia Number 25 of 2014, adolescents are residents in the age range of 10-18 years. According to the Indonesian Ministry of Health in 2009, the age categories of adolescents are early adolescents (12-16 years) and late adolescents (17-25 years) [3].

The development of the structure and function of the body which is more complex in an orderly pattern due to the development of body tissues, organs and organ systems which differentiation from the body's cells is increased so that each can fulfill its function [1]. During adolescence, there are lots of developments, namely moral development, emotional development, special talent development, social relationship development, independence development, language development and psychosocial development [4],[5]. Psychosocial development which includes emotional and social development, cognitive, and moral. Psychosocial development sees individuals based on the combined influence of psychological and social 
factors on a person's mental physical health [5]. At the stage of Erikson's psychosocial development, one of the stages of development in adolescents is looking for self confidence and personal identity. At this stage, adolescents explore themselves in search of self identity. Adolescents who fail to resolve their identity crisis will experience identity confusion (doubt about their identity). This hesitation about withdrawal isolates him from peers and family, or merges himself with the world of peers and loses his identity. And also if the identity development stage is inadequate, it will create psychosocial problems in adolescents such as low self esteem, depression, drug use, and low [6]. Affects psychosocial development in adolescents, namely stimulation, learning motivation, fair punishment, peer groups, stress, development is as well as individual cause, school achievement school, love and affection, and the interaction between children and parents. At the time of formation it is influenced by the social environment of youth identity and can be meaningful. If someone's adolescent socializes with peers without being noticed by their parents, then that teenager will fall into drug abuse [1], [7]. The age categories of adolescents are early adolescents (12-16 years) and late adolescents (17-25 years) [3].

The development of the structure and function of the body which is more complex in an orderly pattern due to the development of body tissues, organs and organ systems which differentiation from the body's cells is increased so that each can fulfill its function [1]. During adolescence, there are lots of developments, namely moral development, emotional development, special talent development, social relationship development, independence development, language development and psychosocial development [4],[5].

Psychosocial development which includes emotional and social development, cognitive, and moral. Psychosocial development sees individuals based on the combined influence of psychological and social factors on a person's mental physical health [5]. At the stage of Erikson's psychosocial development, one of the stages of development in adolescents is looking for self confidence and personal identity. At this stage, adolescents explore themselves in search of self identity. Adolescents who fail to resolve their identity crisis will experience identity confusion (doubt about their identity). This hesitation about withdrawal isolates him from peers and family, or merges himself with the world of peers and loses his identity. And also if the identity development stage is inadequate, it will create psychosocial problems in adolescents such as low self esteem, depression, drug use, and low [6]. Affects psychosocial development in adolescents, namely stimulation, learning motivation, fair punishment, peer groups, stress, development is as well as individual cause, school achievement school, love and affection, and the interaction between children and parents. At the time of formation it is influenced by the social environment of youth identity and can be meaningful. If someone's adolescent socializes with peers without being noticed by their parents, then that teenager will fall into drug abuse [1], [7].

Drug use currently occurs in adolescents. This is evidenced by data from the World Drugs Report 2018, which states that as many as 275 million people in the world or $5.6 \%$ of the world's population (aged 15-64 years) have consumed drugs [8]. In Indonesia there are 990 drug cases in total. This case has decreased from 2017 when there were 1,011 drug cases. As for South Sumatra Province, it ranks 3rd in the number of drug cases, which is 60 cases. The first place in the number of drug cases was in North Sumatra Province with 92 cases followed by East Kalimantan Province with 72 cases [9]. For the South Sumatra region, the number of drug abuse reached 84,925 people with a prevalence of $1.40 \%$. Compared to 2014, the prevalence in the South Sumatra region has decreased by $0.34 \%$ [10].

Drugs are narcotics and drugs or dangerous substances . The term introduced by the Ministry of Health of the Republic of Indonesia is NAPZA (Narcotics, psychotropic, and other addictive substances). Drugs are substances or substances that if they enter the body they will affect the body, especially Narcotics which stands for 11 nervous systems. Center so that if it is abused it will cause physical, psychological and social function disorders.

Drug abuse has an impact negative for teenagers. Impact on physical weight decreases, the eyes are visible sunken and red, face pale, lips become blackish, hands covered with freckles red, defecate and urinate less smoothly, as well as stomach pain for no reason. Psychic impact namely slow to work, careless, often tense, restless, loss of confidence, apathy, fullness suspicious, agitate, become vicious, behave brutal, difficult to concentrate, annoyed, and hurt yourself. Impact on social is anti-social, ostracized by the environment, disrupted education, and the future gloomy [11].

Way to recover or Cure people who use Drugs, namely by means of therapy and Rehabilitation. Useful therapy for lowering and removes toxins from the body. Rehabilitation is an effort to restore and Restore the former's condition Drug abuse or dependence Return to health physically, psychologically, socially, 
and spiritual [12]. Given that teenagers are former addicts Drugs that are undergoing or have been rehabilitating there are still cognitive, emotional, and behavioral problems. Therefore, researchers are interested in differentiating psychosocial development between former adolescents and nondrug users at the Ar-Rahman Foundation. Drug use currently occurs in adolescents. This is evidenced by data from the World Drugs Report 2018, which states that as many as 275 million people in the world or $5.6 \%$ of the world's population (aged 15-64 years) have consumed drugs [8]. In Indonesia there are 990 drug cases in total. This case has decreased from 2017 when there were 1,011 drug cases. As for South Sumatra Province, it ranks 3rd in the number of drug cases, which is 60 cases. The first place in the number of drug cases was in North Sumatra Province with 92 cases followed by East Kalimantan Province with 72 cases [9]. For the South Sumatra region, the number of drug abuse reached 84,925 people with a prevalence of $1.40 \%$. Compared to 2014, the prevalence in the South Sumatra region has decreased by $0.34 \%$ [10]. Drugs are narcotics and drugs or dangerous substances. The term introduced by the Ministry of Health of the Republic of Indonesia is NAPZA (Narcotics, psychotropic, and other addictive substances). Drugs are substances or substances that if they enter the body they will affect the body, especially Narcotics which stands for 11 nervous systems. Center so that if it is abused it will cause physical, psychological and social function disorders.

Drug abuse has an impact negative for teenagers. Impact on physical weight decreases, the eyes are visible sunken and red, face pale, lips become blackish, hands covered with freckles red, defecate and urinate less smoothly, as well as stomach pain for no reason. Psychic impact namely slow to work, careless, often tense, restless, loss of confidence, apathy, fullness suspicious, agitate, become vicious, behave brutal, difficult to concentrate, annoyed, and hurt yourself. Impact on social is anti-social, ostracized by the environment, disrupted education, and the future gloomy [11].

Way to recover or Cure people who use Drugs, namely by means of therapy and Rehabilitation. Useful therapy for lowering and removes toxins from the body. Rehabilitation is an effort to restore and Restore the former's condition Drug abuse or dependence Return to health physically, psychologically, socially, and spiritual [12]. Given that teenagers are former addicts Drugs that are undergoing or have been rehabilitating there are still cognitive, emotional, and behavioral problems. Therefore, researchers are interested in differentiating psychosocial development between former adolescents and nondrug users at the ArRahman Foundation.

\section{METHOD}

This type of research is a research quantitative research design with a comparative study, namely research design which is used to determine the difference between two variables (data) or more. This method will measure the psychosocial development of adolescent ex-users and non- drug users and see if there are differences in psychosocial development between Adolescent ex-drug users and non- drug users at the ArRahman Palembang Foundation The sampling method in this study using a purposive technique sampling of non-drug users. Meanwhile, adolescents who are former drug users use total sampling technique. The number of samples in this study for adolescents who are former drug users as many as 18 respondents and adolescents who are not using drugs as many as 18 respondents.

The research instrument used in this study is the demographic data of the respondents And the Y-PSC 17 Checklist (Youth-Pediatric Symptom Checklist 17). Analysis which Used using Two Independent Sample Tests with the type of Mann Whitney U Test.

\section{RESULTS}

The results of univariate analysis on former adolescents Drug users consist of age, occupation Parents, type of drug used, age Initial drug use, duration of use Drugs, length of rehabilitation, and Psychosocial development (attention, internalization And externalization). While the results are univariate Non-drug users consist of Age, parental occupation, and development Psychosocial. From the research results Implemented are as follows:

Table 1. Age frequency distribution and history of drug use at Rehabilitation Foundation Ar- Rahman $(\mathbf{N}=36)$

Table 1 shows the distribution frequency of

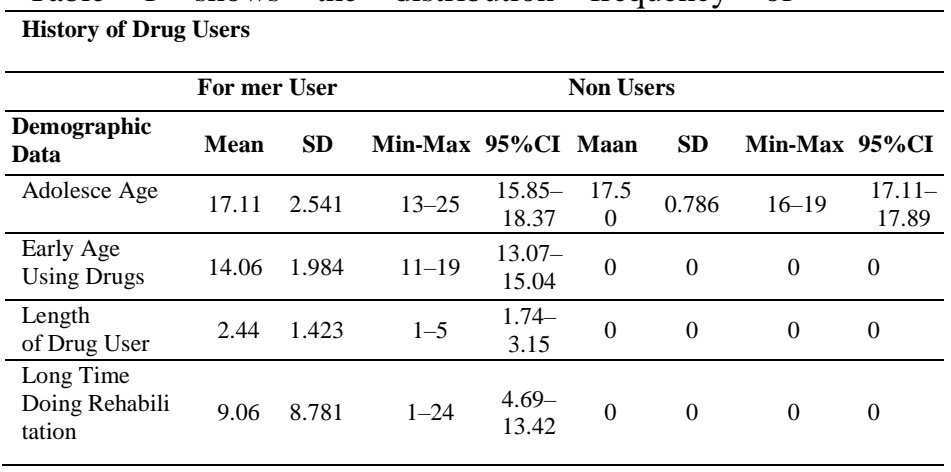


adolescence and history of use drugs. At the age of a former user drugs obtained an average of 17.11 with value standard deviation 2.541 . The lowest teenage age namely 13 years and the highest 25 years. Result $95 \%$ CI, namely 15.85 to 18.37 . While the frequency distribution for non adolescents drug users got an average of 17.50 with a standard deviation value of 0.786. Teenage age the lowest was 16 years and the highest was 19 years. The $95 \%$ CI results were 17.11 to 17.89 . History of drug use in adolescents Former users obtained average age early teens using lowest adolescent age is 11 years And the highest adolescent age was 19. Results $95 \% \mathrm{CI}$, namely 13.07 to 15.04.Long time using drugs is obtained The average is 2.44 with a standard value A deviation of 1,423. Duration of use The fastest drug that is 1 year and Longest drug use is 5 years. The $95 \%$ CI results were 1.74 to 3.15 . For a long time doing rehabilitation Obtained an average of 9.06 with a value Standard deviation of 8,781. Long Perform the fastest rehabilitation, namely 1 Month and the longest is 24 months. Result The $95 \%$ CI was 4.69 to 13.42 .

Table 2. Frequency distribution of demographic data (occupation of parents and types of drug Used) adolescent former users and non-drug users At the Ar-Rahman Foundation $(\mathbf{N}=36)$

\begin{tabular}{lllll}
\hline & \multicolumn{4}{l}{ History of Drug Users } \\
\hline Demographic Data & \multicolumn{2}{l}{ Former } & Non Users & \\
\cline { 2 - 5 } & F & $\%$ & F & $\%$
\end{tabular}

\begin{tabular}{lcrcc}
\hline Father's Job & & & & \\
\hline 1. Self Employed & 7 & 38.9 & 4 & 22.2 \\
\hline 2. Civil Servants & 4 & 22.2 & 1 & 5.6 \\
\hline 3. Private Employees & 5 & 27.8 & 0 & 0 \\
\hline 4. Driver & 1 & 5.6 & 0 & 0 \\
\hline 5. Not Working & 1 & 5.6 & 2 & 11.1 \\
\hline 6. Farmers & 0 & 0 & 7 & 38.9 \\
\hline $\begin{array}{l}\text { 7. Laborers } \\
\text { Mother's Job }\end{array}$ & 0 & 0 & 4 & 22.2 \\
\hline 1. Housewife & 9 & 50.0 & 14 & \\
\hline 2. Private Employees & 2 & 11.1 & 0 & 0 \\
\hline 3. Civil Servants & 6 & 33.3 & 2 & 11.1 \\
\hline 4. Self Employed & 1 & 5.6 & 1 & 5.6 \\
\hline 5. Nurse & 0 & 0 & 1 & 11.1 \\
\hline
\end{tabular}

Type of Drugs Ever Used

\begin{tabular}{clcccc}
\hline 1. & Shabu-shabu & 12 & 33.3 & 0 & 0 \\
\hline 2. & Alcohol & 3 & 8.3 & 0 & 0 \\
\hline 3. & Marijuana & 2 & 5.6 & 0 & 0 \\
\hline 4. & Glue (Inhalation) & 1 & 2.8 & 0 & 0
\end{tabular}

In table 2, shows the distribution the frequency of demographic data on former adolescents Users and non users of drugs. Father's job in former adolescent users most occupational drugs are self-employed totaled 7 people $(38.9 \%)$. For work Private employees amounted to 5 people $(27.8 \%)$, There are 4 civil servants (22.2\%), drivers As much as 1 person $(5.6 \%)$ and who did not Work as much as 1 person with percentage $5.6 \%$. Meanwhile, my father's work in adolescents most non occupational drug users namely farmers amounted to 7 people $(38.9 \%)$. To 4 workers $(22.2 \%)$, self- employed numbered 4 people (22.2\%), civil servants as much as 1 person $(5.6 \%)$ and who did not work as much as 2 people with percentage $11.1 \%$.

Mother's job in former teens Most occupational drug users namely 9 housewives (50\%). For civil servant jobs, there are 6 people $(33.3 \%)$, there are 2 private employees $(11.1 \%)$, and self-employed as many as 1 person $(5.6 \%)$. While the work of mothers in adolescents most non occupational drug users that is, housewives constitute the most Namely, amounting to 14 people (77.8\%). To 2 civil servant jobs (11.1\%), Self employed, amounting to 1 person $(5.6 \%)$, and Nurses as much as 1 person (5.6\%). For the types of drugs that have been used in adolescents of former drug users Ar-Rahman Rehabilitation Center Foundation. Type The drugs that are widely used are meth Crystal methamphetamine amounted to 12 people (33.3\%). To Alcohol as much as 3 people $(8.3 \%)$, marijuana Amounted to 2 people $(5.6 \%)$, and glue (inhalants) amounted to 1 person $(2.8 \%)$.

Table 3. Frequency distribution of ex-user and non adolescent psychosocial development scores Drug users at the Ar-Rahman Foundation $(\mathbf{N}=36)$

\begin{tabular}{lllllll}
\hline $\begin{array}{l}\text { History of } \\
\text { Drug } \\
\text { Users }\end{array}$ & $\begin{array}{l}\text { Psychosocial } \\
\text { development } \\
\text { score }\end{array}$ & Mean & SD & $\begin{array}{l}\text { Min- } \\
\text { Max }\end{array}$ & 95\%CI & $\begin{array}{l}\text { P } \\
\text { Val } \\
\text { ue }\end{array}$ \\
\hline No User & Attention & 4,39 & 0,916 & $3-6$ & $3,93-4.84$ & \\
\cline { 2 - 6 } & Internalization & 4,11 & 1,605 & $1-7$ & $3,31-4,91$ \\
\cline { 2 - 6 } & Externalization & 3,94 & 2,155 & $0-7$ & $2,87-5.02$ \\
\cline { 2 - 5 } & Total Scorer & 12,44 & 3,382 & $8-19$ & $\begin{array}{l}10,76- \\
14,13\end{array}$ & \multirow{2}{*}{0,118} \\
\hline \multirow{2}{*}{$\begin{array}{l}\text { Former } \\
\text { User }\end{array}$} & Attention & 5,17 & 1,534 & $3-8$ & $4,40-5,93$ \\
\cline { 2 - 5 } & Internalization & 4,39 & 2,033 & $1-7$ & $3,38-5,40$ \\
\cline { 2 - 5 } & Externalization & 5,33 & 2,787 & $1-12$ & $3,95-6,72$ \\
\cline { 2 - 5 } & Total Score & 14,89 & 5,234 & $8-12$ & $\begin{array}{l}12,29- \\
17,49\end{array}$ \\
\hline
\end{tabular}

In table 3 above, shows the score psychosocial development in former adolescents users and non users of drugs. On Former adolescent drug user, attention score Obtained an average of 4.39 with value Standard deviation of 2.033. Score The smallest internalization is 1 and the highest is 7 . From the results of the interval estimate can Concluded $95 \%$ believed that the average score Internalization in adolescent former users Drugs are between 3.38 and 5.40. Externalization score in former adolescents Drug users get an average that is 5.33 with a standard deviation value of 2.787 . The smallest externalization score is 1 and a score the highest is 12 . From the interval estimation results It 
can be concluded that $95 \%$ believe that on average externalization score in former adolescents drug users are between 3.95 and with 6.72. Externalization score in adolescents Former drug users were obtained on average Namely 5.17 with a standard deviation value of 1,543. The smallest attention score is 3 and a score the highest is 8 . From the interval estimation results It can be concluded that $95 \%$ believe that on average the average attention score of adolescent former users drugs are between 4.39 and 5.93. For the total progress score Psychosocial in adolescent former users drug obtained growth rate psychosocial is 14.89 with a standard value deviation of 5,234. Development score the lowest psychosocial score was 8 and the highest score is 27 . From the results of the interval estimation can be concluded $95 \%$ believed that on average psychosocial development of former adolescents Drug users are among 12.29 until 17.49.

For non-drug users, the score attentions obtained an average of 4.39 with the standard deviation value is 0.916. Attention score the smallest is 3 and the highest score is 6 . From the results of interval estimation can be concluded $95 \%$ it is believed that the average attention score is at non-drug users are among the teens 3.93 to 4.84. Externalization score In non- adolescents the average was obtained That is 3.94 with a standard deviation value of 2,155 . The smallest externalization score is 0 and The highest score is 7 . From the estimation results $95 \%$ inferred interval is believed that the mean score of externalization in adolescents nondrug users were between 2.87 until 5.02. Internalization score on non-drug users the average is 4.11 with a standard deviation value amounting to 1.605 . The smallest internalization score, namely 1 and the highest score is 7 . From the estimation results $95 \%$ inferred interval is believed that the average internalization score in adolescents non-drug users are among 3.31 until 4.91 .

\section{DISCUSSION}

Ar-Rahman Drug Rehabilitation Foundation is a rehabilitation center for adolescent users drugs. ArRahman Rehabilitation Foundation uses an approach method integrative, namely by means of a therapeutic model physiological medical- based, model psychotherapy based on psychology and models Spiritual based moral healing with development of social interaction skills, giving mental immunity in the face the negative influence of the new social environment, and life skills as a provision live life after doing rehabilitation. Integration approach can be accommodate all dimensions of the damage experienced by drug addicts in such a dimension physical, psychic, and moral spiritual [13]. Different with a partial approach that cannot produces a cure for the addict drugs good in total both physically, psychologically, and spiritual.In this study, all respondent is a teenager with an age range of 12-25 Year. The reason the researchers set the criteria with an age range of 12-25 years due at the time the researchers conducted the initial survey at Ar-Rahman Drug Rehabilitation Foundation the number of respondents aged 12- 18 years only 10 people. Researcher too set a age range of 12- 25 years accordingly with the Indonesian Ministry of Health in 2009. teenagers who are former drug users At the ArRahman Drug Rehabilitation Foundation all of them are male. Based on the research results of [14] there is a relationship between types sex with drug abuse on teenagers. According to Erikson, boys and Women have different personalities because it is influenced by gender. Women are more inclusive and passive meanwhile male is aggressive and prefers to be annoying, so that men experience more problems with the social environment [6].

Most drug use ever used by teenage former users Drugs at the Ar- Drug Rehabilitation Foundation Rahman is shabu-shabu by the start drug use is widely used on 13-16 years old. According to [15] many types of shabu-shabu are consumed by teenagers as an escape from breakups hope. teenagers feel calm and free after using shabu-shabu. Duration of use Drugs in adolescent former users drugs obtained an average of 2.44 with fastest drug use that is 1 year and Longest drug use was 5 years.

Based on the data that has been obtained, father's job on adolescent former users most of the drugs are an entrepreneur while the father's job in non adolescents a drug user is a farmer. For mother work in former teens users and non users of drugs most were housewive (IRT).

The internalization score is average in adolescent former drug users (4.39) greater than the average non adolescent drug users (4.11). This means in adolescents more ex- drug users experiencing internalization problems. However, in adolescent former drug users obtained balanced results between adolescents who experience interference or not experiencing internalization problems, namely totaled 9 people. This is in line with in Cox's opinion, stress on former users subjective effect of drugs is a result felt personally includes restlessness, aggression, lethargy, and low self-esteem feeling of isolation. The externalization score is average in adolescent former drug users $(5,33)$ greater than the average non adolescent drug users (3.94). This means in adolescents more ex-drug users experiencing 
externalization problems. However In adolescent former drug users found as many as 12 adolescents did not experiencing externalization problems. This matter because theAr-Rahman Rehabilitation Foundation applies the Therapeutic Community (TC). TC is a method of rehabilitation social services aimed at victims drug abusers, by using the concept of a family, consisting of people who are have the same problem and purpose The same, to help yourself and Fellow (man helping man to help him self), With the aim to change behavior to better direction.

The average attention score is obtained at adolescent former drug users (5.17) more larger than the average non- adolescent user drugs (4.39). This means in the former teenager more experienced drug users externalization disorder. This is in line with In Cox's opinion, stress on former users cognitive- induced drug that is the result affect thought processes, covering less can concentrate, unable zeroed in timeframe old ones, and experienced mental hindrances.

Based on the research results show That non adolescent drug users in Madrasah Aliyah Ar-Rahman got 5 Adolescents who experience disorders psychosocial development and 13 adolescents who are no developmental disorders psychosocial. Meanwhile, in former adolescents drug users available at the Foundation Rehabilitation Ar-Rahman is average psychosocial development between 12.29 to 17.49. And found 9 teenagers who have developmental disorders psychosocial and 9 adolescents who do not experience psychosocial development disorders development disorders.

Development of cognition, both subjects can solve the problem well, a subject becoming forgetful after taking drugs. In intellectual abilities, the first subject does not experience a decrease in academic achievement [7]. The opposite was experienced by the second subject. Socio-emotional development, both subjects can control emotions. However, the first subject is passive towards activities at neighborhood. Different from second subject active in a wide range activities held by the rehabilitation center drugs.

The results of the Mann Whitney U Test statistical test it was found that the $p$ value $(0.118)>\alpha(0.05)$ it can be concluded that $\mathrm{Ha}$ is rejected. That is, there is no development difference psychosocial among adolescent former users and non drug users. Based on the results these, researchers concluded that between adolescent ex-users and non-users drugs have a chance to experience psychosocial development disorders. This matter influenced by several factors such as stimulation, motivation to learn, fair punishment peer group, stress, school, love and affection, as well as the quality of the child's interactions and parents.

Results of the study is the quality of life for a former drug addict viewed from the physical dimension (energy and Fatigue) is the informant feels much more better at carrying out its activities than when not undergoing rehabilitation [7]. Quality the life of a former drug addict viewed from psychological dimension (positive feelings and negative) are positive feelings pervading self-acceptance, optimism and enthusiasm In undergoing rehabilitation and feelings negatives include shame and regret. Quality the life of a former drug addict viewed from the social dimension (social support) is the informant's relationship with the family tends to be improved so that the informant got emotional support from family and relatives close in carrying out rehabilitation. Quality of life for former drug addicts In terms of the environmental dimension (security Physical) namely the informant does not feel pressure from anywhere and feels safe to move outside the home [16].

The results of this study are also influenced by integration approach implemented by Ar-Rahman Drug Rehabilitation Foundation. The integration approach can accommodate all dimensions of the damage suffered by drug addicts such as the physical, psychological, and spiritual morals[13]. This proves that not all teenagers are former users drugs have developmental disorders psychosocial.

\section{CONCLUSION}

In adolescents, former drug users Not all teenagers experience interference Psychosocial development. Good teenager former users and non users can have developmental disorders psychosocial. Therefore, it needs to be done psychosocial development screening on adolescents using the Youth- Pediatric Symptom Checklist 17 (Y-PSC17) so that it can intervene right early.

\section{ACKNOWLEDGMENT}

The author is grateful to the Polytechnic of Health Ministry of Health Palembang for supporting the implementation of this research. 


\section{REFERENCES}

[1] Cahyaningsih DS. Pertumbuhan Perkembangan Anak dan Remaja. Jakarta Timur: Trans Info Media; 2011.

[2] WHO. Maternal, Newborn, Child \& Adolescent Health. 2019

[3] Soediono B. INFO DATIN KEMENKES RI Kondisi Pencapaian Program Kesehatan Anak Indonesia. J Chem Inf Model 2014;53:160.

[4] Ali M, Asrori M. Psikologi Remaja. Jakarta: Bumi Aksara; 2018.

[5] Suryani, Badi'ah. Asuhan Keperawatan Anak Sehat \& Kebutuhan Khusus. Yogyakarta: Pustaka Baru; 2017.

[6] Sanders RA. Adolescent psychosocial, social, and cognitive development. Pediatr Rev 2013;34:354-9. https://doi.org/10.1542/pir.34-8-354.

[7] Kusumawaty I, Wahyuni S. Penyesuaian Diri Mantan Anak Didik Lembaga Pemasyarakatan Palembang Kelas Iia Saat Kembali Ke Masyarakat Tahun 2012. Kesehatan 2013;1:1-9.

[8] Oficina de naciones Unidas contra la Droga y el Delito (UNODC). Prevention of Drug Use and Treatment of Drug Use Disorders in Rural Settings Special Populations Series Revised Version. United Nation Off Drug Crime 2017:134

[9] Badan Narkotika Nasional. Press release akhir tahun 2019. Bnn 2019:1-33.

[10] BNN. Survei Nasional Penyalahgunaan Narkoba di 34 Provinsi Tahun 2017. J Data Puslitdatin 2017 2017;II:83-8.

[11] Inggriane Puspita Dewi, Siti Ulfah Rifa'atul Fitri. Pemanfaatan Seft Sebagai Modalitas Therapy Community (TC) Untuk Kesehatan Mental Dan Spiritual Pecandu Napza. J Pengabdi UntukMu NegeRI 2020;4:88-94. https://doi.org/10.37859/jpumri.v4i1.1895.

[12] Hawari D. Pendekatan Holistik Pada Gangguan Jiwa Skizofrenia. Jakarta: Fakultas Kedokteran Universitas Indonesia; 2009.

[13] Hawi A. Remaja Pecandu Narkoba: Studi Tentang RehabilitasiIntegratif Di Panti Rehabilitasi Narkoba Pondok Pesantren Ar- Rahman Palembang. Tadrib J Pendidik Agama Islam 2018;4:99https://doi.org/10.19109/tadrib.v4i1.1958.

[14] Wardani EM, Septianingrum Y. Pada Hubungan Antara Persepsi, Jenis Kelamin, Status Tempat Tinggal, Status Orang Tua Dengan Perilaku Penyalahgunaaan Napza Pada Kelas Xi Di Smk Darul Huda Sidoarjo. Med Heal Sci J 2018;2:39-46. https://doi.org/10.33086/mhsj.v2i2.586.

[15] Saputra IS. Psychological Well-Being Remaja Penyalahguna Narkoba. SemNasPsi (Seminar Nas Psikologi) 2018:60-72.

[16] Prasetya, Aynal Mardiyah La Dupai F. Studi kualitatif kualitas hidup mantan pecandu narkoba di klinik rehabilitasi BNN (Badan Narkotika Nasional) kota kendari tahun 2017. J Ilm Mhs Kesehat Masy 2018;3:1-8. 